\title{
Kajian Aksiologi Max Scheler Terhadap Operasi Merubah Kelamin pada Manusia (Transeksual)
}

\author{
Milton Thorman Pardosi ${ }^{1}$, Septiana Dwiputri Maharani ${ }^{2}$ \\ ${ }^{1}$ Universitas Gadjah Mada; Universitas Advent Indonesia) \\ ${ }^{2}$ Universitas Gadjah Mada \\ e-mail: mtpardosi@gmail.com, septianadm@gmail.com
}

\begin{abstract}
Abstrak
Salah satu perkembangan IImu pengetahuan modern saat ini adalah tindakan operasi merubah alat kelamin pada manusia. Ini telah menjadi isu penting dalam masyarakat karena terjadi pro dan kontra. Kelompok yang paling menentang adalah kelompok agama. Beberapa negara sudah melegalkan tindakan ini sementara yang lain belum. Latarbelakang seseorang memutuskan merubah alat kelaminnya ada dua: pertama, karena merasa sedang berada di dalam "tubuh yang salah" di mana perilakunya bertolak belakang dengan alat genital yang dimiliki. Kedua, perkembangan alat genital yang tidak sempurna. Itu sebabnya perlu dibuat kajian Aksiologi terhadap keputusan merubah alat kelamin pada manusia tersebut. Aksiologi sendiri berarti ilmu atau teori tentang hakikat nilai yang menyelidiki nilai dalam hal hakikatnya, ukurannya, dan status metafisisnya yang berkaitan dengan kegunaannya. Dalam Aksiologi, Max Scheler memberikan empat tingkatan nilai yaitu: (1) Nilai "kenikmatan" atau "kesenangan" (agreeable) dan "ketidaknikmatan" atau "ketidaksenangan" (disagreeable); (2) Nilai vitalitas atau kesejahteraan atau kehidupan (vital feeling); (3) Nilai spiritual (spiritual values); (4) Nilai kekudusan atau keprofanan atau ketuhanan (the holy). Dari keempat hakikat nilai Max Scheler tersebut didapati bahwa keputusan merubah alat kelamin pada manusia tidak memiliki hakikat nilai apapun kecuali sekedar nilai kenikmatan atau kesenangan. Artinya, tindakan semacam ini sesungguhnya menyangkal hakikat nilai-nilai yang ada. Nilai kenikmatan yang didapatkan melalui operasi merubah kelamin sebenarnya hanya bersifat "fana" atau sesaat karena justru kekecewaanlah yang muncul pada akhirya. Oleh sebab itu, penulis menyarankan agar mereka yang merasa diri terjebak di dalam "tubuh yang salah" lebih baik melakukan terapi kejiwaan dan keagamaan agar hakikat nilai yang ada pada dirinya dapat diperkembang ketimbang melakukan perubahan pada alat kelamin.
\end{abstract}

Kata Kunci: Operasi Kelamin, Aksiologi, Kodrat.

\begin{abstract}
One of the developments in modern science today is surgery to change genitals in humans. This has become an important issue in society because of the pros and cons. The most opposed groups are religious groups. Some countries have legalized this action while others have not. The backgrounds of people deciding to change their genitals are twofold: first, because they feel they are in the "wrong body" where their behavior is contrary to the genitals they have. Second, the development of genital devices is not perfect. That is why an axiology study needs to be made on the decision to change the genitals in humans. Axiology itself means the science or theory of the nature of values which investigates values in terms of their nature, their size, and their metaphysical status relating to their usefulness. In Axiology, Max Scheler gave four levels of value, namely: (1) The value of "enjoyment" or "pleasure" (agreeable) and "dislike" or "displeasure" (disagreeable); (2) The value of vitality or welfare or life (vital feeling); (3) Spiritual values; (4) Holiness or holy value. Of the four values of Max Scheler, it was found that the decision to change the genitals in humans does not have the essence of any value except just the value of enjoyment or pleasure. That is, this kind of action actually denies the nature of existing values. The value of enjoyment obtained through sex change surgery is actually only "mortal" or for a moment enjoyment because it is precisely the disappointment that appears at the end. Therefore, the authors suggest that those who feel themselves trapped in the "wrong body" are better off doing psychiatric and religious therapy so that the nature of the values that they have can be developed rather than making changes to the genitals.
\end{abstract}

Keywords: Genital Surgery, Axiology, Nature. 


\section{Pendahuluan}

Manusia adalah makhluk yang tertinggi derajatnya dibandingkan makhluk-makhluk lain yang ada di atas bumi ini. Di saat yang sama, manusia juga memiliki karakteristik, kekhasan dan menyimpan berjuta misteri yang berbeda satu dengan yang lain (Maharani, Filsafat Manusia: Unsur-Unsur dan Problematikanya, 2008: v). Satu definisi lama menyatakan bahwa "manusia adalah binatang yang berakal budi atau animal rationale (Peursen, 1990: 1). Ini artinya, manusia adalah makhluk yang berpikir, memiliki kecerdasan dan kemampuan daya cipta yang digunakan bagi kebutuhan dan perkembangan hidupnya.

Salah satu hasil dari kemampuan yang manusia miliki tersebut adalah munculnya IImu Pengetahuan dan Teknologi (IPTEK). IPTEK mencakup banyak aspek ilmu yang bisa berdampak positif maupun negatif bagi manusia karena semuanya itu bergantung pada tujuan IPTEK ditemukan, siapa yang menggunakannya, norma-norma, nilai atau etika serta kaidahkaidah agama yang ada.

Di satu sisi, benarlah bahwa setiap IPTEK pasti memiliki nilai-nilai yakni nilai subjektif, objektif, atau objektif metafisik tentang nilai dalam Aksiologi (Katsoff, 2004: 323). Namun, di sisi lain, ada hal yang perlu diingat bahwa "ilmu perlu dikembangkan dengan terbebas dari belenggu-belenggu dogma yang bisa menghambat perkembangan ilmu itu sendiri" (Maharani, Persoalan-Persoalan Nilai dalam Klonasi Manusia, 2008: 1). Itu berarti, IPTEK, dalam perkembangannya, menghadapi dilemma. Pertama, jika IPTEK berbasis kepada nilai-nilai, maka kemungkinan besar perkembangannya akan terhambat. Sebaliknya, jika IPTEK bebas dari nilai-nilai, IPTEK akan berkembang dengan cepat namun kemungkinan besar akan membawa masalah bagi kehidupan manusia.

Di sini manusia melihat bahwa perkembangan IPTEK yang luar biasa bisa menyebabkan manusia "lupa diri" atau lupa akan kodratnya. Manusia menjadi bersifat individualis, egois dan eksploitatif, baik terhadap diri sendiri, sesama, masyarakat, alam lingkungan, bahkan terhadap Sang Pencipta. Itu sebabnya Aksiologi sangat diperlukan di tengah-tengah perkembangan dan keanekaragaman IPTEK untuk meluruskan jalan dan menepatkan fungsinya bagi kehidupan manusia di dunia ini.

Menyikapi hal ini, Hugh Lacey menyimpulkan hubungan antara ilmu pengetahuan (fakta) dengan nilai:

1. Ilmu bebas nilai. Maksudnya, ilmu itu memang bebas nilai yang didasari oleh otonomi dan netralitas ilmu itu sendiri (Lacey, 1999: 2).

2. Nilai tidak terlepas dari fakta. Lacey menyatakan: "the fact and value components cannot be separated. To the extent that science is value free represents a fact, or an idealization of a fact, that is because science is value free has been held as a value; and its being held as a value is without foundation if it is not possible for it to be increasingly manifest in fact" (Lacey, 1999: 2). Maksudnya, fakta dan komponen nilai tidak dapat dipisahkan. Sejauh bahwa ilmu pengetahuan adalah bebas nilai menyatakan fakta, atau idealisasi akan fakta, itu karena ilmu pengetahuan adalah bebas nilai telah dianggap sebagai nilai; dan yang dipegang sebagai nilai adalah tanpa dasar jika itu tidak mungkin baginya menjadi semakin nyata dalam kenyataan.

3. Ilmu bersifat otonomi. Terkait otonomi ilmu, Lacey menyatakan: "autonomy also draws on the idea that science has its own internal dynamic, that science defines its own problems, ask its own questions, identifies its own research priorities, seeking to gain ever more accurate, more unified, more encompassing representations of the underlying order" (Lacey, 1999: 9). Artinya, "Otonomi juga mengacu pada gagasan bahwa ilmu pengetahuan memiliki dinamika internalnya sendiri, bahwa ilmu pengetahuan mendefinisikan masalahnya sendiri, mengajukan pertanyaannya sendiri, mengidentifikasi prioritas penelitiannya sendiri, berusaha mendapatkan representasi yang lebih akurat, lebih utuh, dan lebih menyeluruh dari tatanan yang mendasarinya.

4. Ilmu bersifat netral. Lacey menyimpulkan bahwa: "Neutrality, so understood, is frame by 'progress' or 'development', by the modern values control. The essential link with these values is not taken as a sign of the absence of neutrality (as such a link with any other values would be) only because it is assumed that the modern values of control have become universal values" (Lacey, 1999: 243). Artinya, netralitas, begitu dipahami, adalah bingkai oleh 'kemajuan' atau 'pengembangan,' oleh kontrol nilai-nilai modern. Hubungan penting dengan nilai-nilai ini tidak diambil sebagai tanda tidak adanya kenetralan (seperti hubungan dengan nilai lain) hanya karena diasumsikan bahwa kontrol nilai-nilai modern telah menjadi nilai universal. 
Salah satu kemajuan IPTEK di abad ini adalah tindakan operasi merubah alat kelamin pada manusia (transeksual). Tindakan operasi ini telah menimbulkan kontrovesi baik di kalangan agama, psikologi, budayawan, dokter, dll. Ada yang mendukung dengan dalil kemanusiaan untuk melepaskan seseorang dari rasa tidak puas atau rasa terjebak dalam "tubuh yang salah." Pandangan lain didasarkan pada penegakan keadilan yang menyangkut hak asasi manusia. Kelompok yang kedua justru tidak mengambil sikap apapun. Sementara kelompok yang terakhir menolak dengan tegas atas dasar etika dan agama.

Di kalangan dokter sendiripun masih belum ada kesepakatan karena bergantung pada prinsip ilmu pengetahuan dan keyakinan yang dimiliki sang dokter itu sendiri. Ada dokter bedah yang mau melakukannya karena tanggungjawab profesi atau mungkin juga keuntungan materi yang didapatkan dan ada juga yang menolak. Salah satunya pernyataan dari Prof. Dr. Djohansyah Marzoeki, Guru Besar Fakultas Kedokteran UNAIR, yang dilaporkan oleh Guntur Merdekawan. Marzoeki menyatakan bahwa operasi merubah kelamin yang dilakukannya bukanlah karena hobi melainkan tanggungjawab profesi seorang dokter. Seorang dokter bekerja untuk ilmu kedokteran di mana ilmu kedokteran itu sendiri dikawal oleh dua pokok penting yaitu: sumpah dokter dan etika kedokteran. Kalau kedua pokok penting ini sudah terpenuhi, maka tindakan medis apapun bukan lagi sebuah masalah (Merdekawan, 2018).

Beberapa negara di dunia ini telah melegalkan operasi merubah kelamin. Seperti di Amerika, tindakan itu bergantung kepada undang-undang negara bagian. Negara bagian Texas dan New York telah melegalkan operasi merubah kelamin demikian juga di Belanda dan Australia. Namun di Thailand masih belum ada pengaturan yang pasti meskipun di negara ini operasi merubah kelamin marak dilakukan (Klarisa dan Sampurna, 2017: 165-166).

Di Indonesia sendiri tindakan operasi ini resmi diijinkan melalui keputusan Menteri Kesehatan Nomor: 191/MENKES/SK/III/1989. Namun izin ini diberikan dengan persyaratan yang ketat di mana hanya Rumah Sakit-Rumah Sakit yang ditunjuk oleh pemerintahlah yang bisa melakukannya dan harus ada tim dokter khusus yang dibentuk untuk melakukannya. Bilamana proses transeksual sudah selesai, maka orang tersebut bisa memilih apakah ia akan merubah status kelaminnya melalui Pengadilan Negeri dan Dinas Kependudukan dan Catatan Sipil atau tidak. Jika ya, ia akan menjalani proses melaporkan status gender barunya ke Pengadilan Negeri dan dilanjutkan ke Dinas Kependudukan dan Catatan Sipil untuk mengganti data jenis kelaminnya. Proses ini pun sudah resmi dengan dikeluarkannya Undang-Undang Dinas Kependudukan dan Catatan Sipil Kependudukan Nomor: 23 Tahun 2006 Penjelasan Pasal 57 ayat 1 dan diubah dengan Undang-Undang Nomor: 24 Tahun 2013 Pasal 56 di mana dikatakan bahwa "pencatatan peristiwa penting lainnya dilakukan oleh Pejabat Pencatatan Sipil atas permintaan yang bersangkutan setelah adanya penetapan Pengadilan Negeri yang telah memperoleh kekuatan hukum tetap. Di dalam penjelasan disebutkan bahwa 'Peristiwa Penting lainnya' adalah peristiwa yang ditetapkan oleh pengadilan negeri untuk dicatatkan pada Instansi Pelaksana, antara lain merubah jenis kelamin" (Klarisa dan Sampurna, 2017: 167).

Melihat hal-hal yang telah diuraikan di atas, penulis merasa perlu membuat kajian Aksiologi terhadap keputusan dan tindakan merubah alat kelamin pada manusia agar siapapun yang ingin atau telah melakukan perubahan alat kelamin dapat mengerti kembali hakikat nilai dari keputusan itu sendiri. Tujuannya adalah agar masing-masing individu dapat merenungkan kembali nilai-nilai dari kepetusan tersebut sebelum mengambil keputusan lebih jauh. Adapun kajian Aksiologi yang dimaksudkan di sini bertujuan untuk melihat manfaat dan kerugian (nilai dan kegunaan) operasi tersebut secara khusus bagi si pasien, keluarga maupun masyarakat secara umum.

Adapun rumusan masalah dalam penelitian ini adalah: (1) Apakah Aksiologi itu?; (2) Apakah yang melatarbelakangi seseorang merubah alat kelamin?; (3) Bagaimana kajian Aksiologi Max Scheler terhadap operasi merubah alat kelamin pada manusia? Sementara tujuan dari penelitian ini adalah untuk: (1) Memahami Aksiologi; (2) Mengetahui latarbelakang seseorang merubah alat kelaminnya; (3) Memahami kajian Aksiologi Max Scheler terhadap tindakan merubah alat kelamin pada manusia.

\section{Metode}

Adapun metode penelitian yang digunakan dalam penelitian ini adalah metode penelitian kualitatif yang "lebih menekankan pada segi kualitas secara alamiah karena menyangkut pengertian, konsep, nilai serta ciri-ciri yang melekat pada objek penelitian" (Kaelan, 2005: 5). Danim (Danim, 2002: 35) menyatakan bahwa "pendekatan filosofis dan aplikasi metode dalam 
kerangka penelitian kualitatif dimaksudkan untuk memproduk ilmu-ilmu 'lunak' (soft sciences)... Esensinya adalah sebagai sebuah metode pemahaman atas keunikan, dinamika, dan hakikat holistik dari kehadiran manusia dan interaksinya dengan lingkungan." Itu sebabnya dalam penulisan makalah ini, penulis menelaah pustaka dengan cara pengumpulan informasi dari berbagai sumber seperti buku, jurnal, maupun artikel-artikel dari internet.

\section{Hasil dan Pembahasan}

Dalam bagian pembahasan ini, akan dibahas hal-hal yang menjadi rumusan masalah dan tujuan penelitan yaitu: Pengertian Aksiologi; Latarbelakang seseorang merubah alat kelamin; dan terakhir, Kajian Aksiologi terhadap tindakan merubah alat kelamin pada manusia.

Aksiologi

Kata Aksiologi berasal dari bahasa Yunani yaitu axios (nilai, berharga) dan logos (uraian atau teori). Aksiologi adalah ilmu atau teori tentang nilai yang menyelidiki nilai dalam hal hakikatnya, ukurannya, dan status metafisisnya (Mudhofir, 2014: 42). Kattsoff (Kattsoff, 2014: 319) mendefinisikan aksiologi sebagai ilmu pengetahuan yang menyelidiki hakikat nilai, yang umumnya ditinjau dari sudut pandang kefilsafatan. Sementara Jujun Suriasumantri (Suriasumantri, 2001:34) menambahkan arti aksiologi sebagai teori nilai yang berkaitan dengan kegunaan.

Menurut Bramel yang dikutip oleh Edwards (Edwards, 1967: 106), Aksiologi itu terbagi menjadi tiga bagian yaitu: pertama, Moral Conduct, yaitu tindakan moral, bidang ini melahirkan disiplin khusus, yaitu etika. Menurut Assalam (Assalam, 1995: 139) etika adalah filsafat tentang pola tingkah laku yang baik dan buruk. Kedua, Esthetic Expression, yaitu ekspresi keindahan. Ini adalah filsafat tentang pola cita rasa atau kreasi yang indah dan yang jelek (Asssalam, 1995: 139). Ketiga, Sosio-Political Life, yaitu kehidupan sosial politik, yang akan melahirkan filsafat sosio-politik.

Intinya, Aksiologi berbicara tentang nilai. Mukhtar Latif (Latif, 2014: 232) mengartikan nilai atau value sebagai keberhargaan (worth) atau kebaikan (goodness). Sementara menurut Kaelan (Kaelan, 2002: 13) nilai atau value diartikan sebagai keberhargaan (worth), isi dan pesan, dan teori sehingga bermakna secara fungsional dan kebaikan (goodness). Dari definisidefinisi di atas, nilai harus dibedakan dengan benda. Pada dasarnya nilai bukanlah benda, bukan juga pengalaman, bukan juga esensi, tapi nilai adalah nilai itu sendiri. Singkatnya, nilai itu selalu bersifat ideal sementara fakta hanyalah yang tampak.

Max Scheler, yang dikutip oleh Wahana (Wahana, 2004:52), menyatakan bahwa nilai merupakan kualitas yang tidak bergantung pada pengembannya. Sesuatu objek boleh saja mengalami merubah, tetapi nilai dalam barang atau objek itu tetap tidak akan pernah berubah. Yang kedua, Scheler, sebagaimana dikutip oleh Wahana (Wahana, 2004: 53) juga menolak ketergantungan nilai pada realitas kehidupan karena jika tergantung pada realitas kehidupan, maka itu akan meniadakan kemungkinan untuk menambah nilai dalam kehidupan itu sendiri. Intinya, sebagaimana yang disimpulkan oleh Kumoro, "kualitas nilai tidak berubah ketika pembawanya berubah, demikian pula tidak akan rusak saat pembawanya rusak atau mati" (Kumoro, 2012: 83).

Di sisi lain, hakikat nilai itu sendiri menurut Mulyana (Mulyana, 2004: 78) adalah suatu rujukan dan keyakinan dalam menentukan pilihan, di mana perwujudannya dapat berupa norma, etika, peraturan, adat kebiasaan, aturan agama, dan lain sebagainya. Busro (Busro, 1989: 1) menyatakan bahwa hakikat nilai itu sendiri adalah dikotomis dalam arti positif dan negatif, berharga dan tidak berharga, berguna dan tidak berguna, baik dan tidak baik, benar dan salah, baik atau buruk. Intinya, suatu benda dapat disebut bernilai hanya dengan menggunakan indera (dirasakan) dan pikiran atau dihayati (Wahana, 2004: 70).

Frondizi yang dikutip oleh Subagyo (Subagyo, 2015: 47-48) memberikan beberapa karakteristik nilai yaitu: Nilai adalah kualitas yang tidak riil. Ini berarti nilai membutuhkan pengemban untuk berada. Kedua, nilai adalah polaritas (Positif dan Negatif). Nilai polaritas ini adalah melalui dirinya sendiri. Terakhir, Nilai tersusun secara hierarkis di mana ada yang lebih tinggi dan ada yang lebih rendah, yang paling penting hingga yang kurang penting.

Sementara menurut Bahm (Bahm, 1984: 51) ada dua belas jenis nilai yang masingmasingnya berpasangan satu sama lain yaitu:

1. Baik dan Buruk atau "Good and Bad" (Memaksimalkan kebaikan dan meminimalkan keburukan);

2. Tujuan dan Sarana atau "Ends and Means" (Sarana sebagai nilai instrumental, dan tujuan sebagai nilai intrinsik); 
3. Nilai Subjektif dan Objektif atau "Subjective and Objective Values" (Subjek dan objek bersifat korelatif; suatu objek selalu merupakan perhatian bagi subjek, dan subjek selalu menyadari keberadaan suatu objek;

4. Nilai yang menampak dan yang riil atau "Apparent and Real Values" (Objek tersebut hadir dan diterima sebagai sesuatu yg kelihatan atau menampak; objek tetap real atau mereka eksis meskipun tidak ada dalam kesadaran seseorang atau tidak menampak);

5. Nilai aktual dan potensial atau "Actual and Potential Values" (Semua perasaan bersifat sementara; nilai intrinsik terdapat dalam rasa suka dan duka yang sifatnya sementara; Semua perasaan ada penyebabnya; nilai instrumental adalah semua sebab dan kondisi dari kejadian nilai intrinsik; nilai intrinsik bersifat temporer dan sesungguhnya hanya ada dalam denyut kesadaran);

6. Nilai Murni dan Campuran atau "Pure and Mixed Values." Nilai Murni meliputi empat jenis perbedaan antara baik dan buruk: rasa senang atau tidak; bersemangat atau lesu; rasa puas atau frustrasi; rasa tenang atau terganggu. Sementara Nilai Campuran adalah perpaduan berbagai nilai: nilai aktual dan potensial; nilai subjektif dan objektif; nilai yang menampak dan yang riil.

Max Scheler (Scheler, 1994: 13) menyatakan nilai berlaku menurut hierarki: pertama, semakin tinggi peringkat nilai, semakin sedikit nilai-nilainya yang dibagi dan dikendalikan. Artinya, makin dapat dibagi tanpa mengurangi maknanya, nilainya makin tinggi. Kedua, semakin tinggi peringkat nilai, semakin bertahan di dalam waktu. Dalam hierarki ini, semakin lama nilai itu bertahan akan semakin baik. Ketiga, semakin tinggi peringkat nilai, semakin sedikit nilai-nilainya dapat diwujudkan (willed) dan dikelola. Ketergantungan relatif suatu nilai dari nilai lainnya; makin tidak tergantung pada kenyataan lainnya makin tinggi nilainya. Terakhir, semakin tinggi peringkat nilai, semakin nilai-nilainya menghasilkan kepuasan pribadi, kebahagiaan dan kedamaian. Intinya, Max Scheler berpendapat sebagaimana dikutip oleh Kaelan (Kaelan, 2007: 20) bahwa nilai-nilai yang ada tidak sama luhurnya dan sama tingginya karena nilai-nilai tersebut menjadi tolak ukur dalam menilai dan penilaian.

Itu sebabnya, Max Scheler, yang dikutip oleh Wahana (Wahana, 2004: 60-62), membagi nilai ke dalam empat tingkatan:

1. Pertama, nilai "kenikmatan" atau "kesenangan" (agreeable) dan "ketidaknikmatan" atau "ketidaksenangan" (disagreeable): ini terkait kepada nilai-nilai yang mengenakkan dan tidak mengenakkan atau yang menyenangkan dan tidak menyenangkan. Sering disebut nilai menyangkut fisik. Nilai ini lebih disukai dan dapat dipastikan bahwa setiap orang akan memilih yang menyenangkan atau membawa dan memberikan kenikmatan (Wahana, 2004: 61). Tingkatan nilai ini berkaitan dengan fungsi inderawi yaitu rasa nikmat, rasa sakit dan pedih. Hetharia (Hetharia, 2014: 69) menyimpulkan bahwa nilai ini adalah hierarki yang terendah karena merupakan nilai yang pada dasarnya "fana."

2. Kedua, nilai vitalitas atau kesejahteraan atau kehidupan (vital feeling): di sini terdapat nilainilai yang penting bagi kehidupan seperti kesehatan, kesegaran jasmani dan kesejahteraan umum dan nilai-nilai kejiwaan (Kaelan, 2002: 125). Ini berkaitan dengan bagus dan jelek, halus dan kasar, luhur atau biasa. Keadaan yang terkait adalah kesehatan, vitalitas, penyakit, lanjut usia, lemah dan rasa mendekati kematian (Wahana, 2006:61). Menurut Hetharia (Hetharia, 2014: 70), nilai ini tidak dapat dinaikkan pada nilai spiritual atau diturunkan pada nilai kesenangan. Mengapa? Karena menurut Scheler "suatu nilai dapat berada lebih tinggi dari nilai lain bila nilai itu merupakan dasar bagi nilai yang lain" (Hetharia, 2014:70).

3. Selanjutnya adalah nilai spiritual (spiritual values): ini menyangkut nilai estetis, nilai benarsalah, adil-tidak adil. Nilai ini tidak bergantung pada seluruh lingkungan badaniah atau alam sekitar. Kaelan (Kaelan, 2002: 125) berpendapat bahwa dalam tingkatan nilai spiritual terdapat nilai-nilai kejiwaan di mana pada nilai ini melekat keindahan, kebenaran dan pengetahuan murni yang dicapai dalam filsafat.

4. Nilai kekudusan atau keprofanan atau ketuhanan (the holy): di mana pada tingkatan ini terdapatlah moralitas nilai suci dan tidak suci. Nilai ini, sebagaimana disampaikan Wahana (Wahana, 2004: 61) hanya tampak pada objek yang dituju sebagai objek absolut. Sementara nilai-nilai turunannya adalah nilai-nilai barang dalam pemujaan, sakramen dan bentuk-bentuk ibadat, sejauh terkait dengan Pribadi yang dipuja. 


\section{Latarbelakang Seseorang Merubah Alat Kelamin}

Bila dilihat secara umum, faktor pemicu seseorang melakukan operasi merubah alat kelaminnya karena orang tersebut sudah tidak betah atau mungkin tidak bisa menerima jenis kelamin yang dibawanya sejak lahir. Kebencian tersebut dipicu oleh banyak sebab. Kemungkinan pertama adalah salah didik sejak kecil. Orang tua tidak melakukan pendekatan kejiwaan, keagamaan, penjelasan, pencegahan, dan juga pengarahan serta terapi kepada anak-anak mereka ketika mereka melihat bahwa anak-anaknya memiliki kecenderungan perilaku yang berbeda dengan jenis kelaminnya.

Para calon pasien sebenarnya memiliki jenis kelamin yang jelas dan tidak samar, baik dari segi penampilan luar maupun organ internalnya. Untuk kelompok ini, Klarisa dan Sampurna (Klarisa dan Sampurna, 2017: 163) menjelaskan bahwa "di Indonesia, dalam memandang gender identity disorder beberapa ahli masih menggunakan Pedoman Penggolongan Diagnosis Gangguan Jiwa/PPDGJ ke III yang mengacu pada DSM IV dan diterbitkan tahun 1995, di mana keadaan ini masih dianggap sebagai suatu gangguan kejiwaan yang seharusnya diperbaiki atau diterapi tanpa harus mengubah jenis kelamin." Untuk kasus seperti ini pendekatan psikologis dan religius adalah baik dilakukan.

Hal kedua adalah seseorang itu merasa dia berada dalam "tubuh yang salah." Ini disebut juga jenis kelamin yang samar atau ganda (gender identity disorder). Penulis di sini menyampaikan apa yang Klarisa dan Sampurna (Klarisa dan Sampurna, 2017: 161-163) ringkaskan tentang dua jenis gender identity disorder:

1. Gender nonconformity atau transgender identity.

a. Jenis ini terjadi saat seseorang merasakan adanya keganjilan pada gender berdasarkan kromosom, hormon, organ, dan karakteristik seksual sekunder yang didapat sejak lahir. Kelainan seperti ini dapat mempengaruhi orang tersebut dalam menjalani hidupnya.

b. Contohnya, pada penderita sindrom Klinefelter di mana tubuhnya adalah perempuan namun pelan-pelan muncul testis di alat kelaminnya sehingga membuat sang individu bingung. Individu yang mengalami kelainan kondisi medis ini berusaha untuk menyesuaikan dengan jenis kelamin yang seharusnya (yang baru muncul), meski mungkin ia sendiri sudah hidup dengan jenis kelamin lain (yang sebelumnya) sepanjang hidupnya.

2. Gender dysphoria.

a. Ini terjadi ketika identitas gender seseorang tidak sesuai dengan yang dimilikinya dengan disertai rasa tidak nyaman dan tidak suka terhadap karakteristik gender eksternal dan memiliki keinginan untuk merubah secara berbeda dari saat lahir.

b. Sebagai contoh seorang yang lahir sebagai laki-laki tetapi merasa di dalam dirinya adalah seorang perempuan, sehingga dalam kesehariannya orang tersebut akan mengenakan atribut perempuan.

c. Hal-hal yang akan dilakukan oleh individu dalam kondisi ini adalah: 1) Bertahan dengan jenis kelamin yang dirasakan di dalam dirinya meski bertentangan dengan penampilan fisik, atau, 2) Mencari teman yang sesuai dengan jenis kelamin yang dirasakan, atau, 3) Menghindari mainan yang tidak sesuai dengan jenis kelamin yang dirasakan, atau, dan 4) Memilih kencing dengan posisi jongkok daripada berdiri (jika dia merasa dirinya perempuan padahal lelaki) dan sebaliknya.

d. Ketidaknyamanan yang dirasakan ini dapat menimbulkan kecemasan, stress, maupun depresi sehingga dapat mengganggu fungsi hidup sehari-hari. Bahkan bilamana terus berkepanjangan dan tidak teratasi dapat menimbulkan kegilaan serta keinginan untuk bunuh diri.

e. Seseorang dalam kondisi ini disarakan untuk menemui ahli kejiwaan untuk mendapatkan terapi kejiwaan. Namun bilamana tetap tidak terlihat perubahan, maka langkah selanjutnya adalah terapi hormon, dan bilamana belum berhasil tindakan operasi merubah jenis kelamin akan disarankan.

Aisyah Putri (Putri, 2016) memberikan kisah singkat latarbelakang keputusan seseorang menjalani operasi merubah alat kelamin pertama di dunia. Dikisahkan seorang pria bernama Rudolph Richter yang dilahirkan di Erzgebirge, Jerman pada tahun 1891. Awalnya Rudolf adalah seorang pria sejati, namun lama kelamaan ia justru menunjukkan sifat-sifat perempuan. Bahkan di usia 6 tahun, Rudolf mencoba memotong alat kelaminnya sendiri sebagai bentuk protes akan kondisi dirinya yang secara fisik adalah seorang pria namun perilakunya justru perilaku seorang perempuan. la juga pernah dipenjara beberapa kali karena mengenakan pakaian wanita di depan umum walau fisiknya adalah seorang laki-laki. 
Hakim yang mengadili Rudolf merasa kasihan dan memintanya untuk menemui Magnus Hirschfeld, seorang sexolog terkemuka di Jerman. Rudolf akhirnya ditampung di institut sexologi milik Magnus di mana ia bekerja di situ dan bebas menggunakan pakaian yang ia inginkan. Magnus memanggil Rudolf dengan panggilan "Dorchen" atau "Dora kecil." Pada tahun 1922, Rudolf alias "Dora" dikastrasi (kebiri) atas permintaannya sendiri. Setelah kastrasi dilakukan, Magnus Hirschfeld meneliti perkembangan tubuh Rudolf. la ingin mengetahui pengaruh pengurangan hormon testosteron pada anatomi tubuh pasiennya tersebut. Dari penelitian yang ia lakukan pada "Dora," ia menemukan bahwa kastrasi memiliki dampak pada tubuh pasiennya meskipun tidak terlalu mencolok. Tubuh "Dora" menjadi lebih montok, pertumbuhan janggutnya melambat, dadanya tumbuh, dan pinggulnya melebar. Pada tahun 1931, "Dora" atau Rudolf setuju untuk melakukan vaginoplasty dan menjadi perempuan sepenuhnya. Dora akhirnya menjadi manusia transgender pertama di dunia. Dari kisah singkat ini dapat disimpulkan bahwa seseorang mau melakukan operasi perubahan kelamin pada dirinya adalah mencari solusi dari ketidakpuasan dan rasa bingung yang terjadi pada dirinya terkait perbedaan antara fisik (alat genital) dan sifat-sifat yang ditunjukkan.

Latarbelakang berikutnya, seperti yang disampaikan Dr. Irena Sakura Rini (Anwar, 2018), seorang spesialis bedah, adalah bahwa "proses operasi kelamin sendiri bukan mengganti total dari organ reproduksi pria menjadi wanita atau sebaliknya. Tidak ada transplantasi karena dokter hanya merekonstruksi apa yang sudah ada agar jadi lebih 'sesuai.' Biasanya dia sudah ada membawa (kelamin -red) itu dari lahir yang tersembunyi... Bisa karena tidak terbentuk sempurna, setengah-setengah. Untuk laki-laki misalnya dia tidak punya organ laki-laki tapi ada setengahnya perempuan, misalnya sel telurnya kecil sekali. Laki-laki kan tidak punya sel telur tapi orang ini memiliki, ada kelenjar susu yang lebih dari seharusnya. Kondisi kelainan-kelainan seperti itu yang dapat diperbaiki dengan operasi kelamin." Ini artinya, seseorang itu sebenarnya hanya merekonstruksi genital yang ada sejak lahir karena pertumbuhan genital yang tidak sempurna.

Kajian Aksiologi Max Scheler Terhadap Tindakan Merubah Alat Kelamin Pada Manusia

Dalam menyikap tindakan operasi merubah alat kelamin pada manusia, didapati terjadi konflik nilai. Konflik nilai itu sendiri terjadi karena ada benturan perspektif yang disebabkan cara pandang yang berbeda, keunikan, individualitas, perbedaan kepentingan atau prioritas, motivasi dan sebagainya (Maharani, Persoalan-Persoalan Nilai dalam Klonasi Manusia, 2008: 30). Itu sebabnya, dibutuhkan suatu cara atau teknik di dalam menyelesaikan konflik yang muncul. Ini yang sering disebut dengan "win-win situation" tanpa merusak keunikan masing-masing titik pijak atau sudut pandang (Maharani, Persoalan-Persoalan Nilai dalam Klonasi Manusia, 2008:31).

Itu sebabnya, di bagian akhir ini, penulis menyampaikan kajian Aksiologi menurut Max Scheler dengan masing-masing klasifikasi nilai yang ditawarkan. Adapun kajian Aksiologi terhadap tindakan merubah alat kelamin menurut klasifikasi Aksiologi Max Scheler adalah:

1. Nilai kenikmatan atau kesenangan dan ketidaknikmatan dan ketidaksenangan. Keputusan seseorang merubah alat kelamin pada diirnya boleh jadi membawa nilai kenikmatan atau kesenangan bagi orang tersebut. la pada akhirnya merasa senang karena telah lepas dari "tubuh yang salah." Orang tersebut sekarang merasa lebih bebas berperilaku sesuai dengan kelamin "baru" yang ia miliki dengan sifat-sifat yang sejalan dengan kelamin "baru"nya tersebut. Namun menurut fakta yang ada, banyak mereka yang sudah melakukan perubahan alat kelamin justru menjadi bingung, menyesal, gelisah dan bahkan telah atau ingin melakukan kembali perubahan pada alat kelaminnya agar kembali seperti semula. Kenyataan yang terjadi justru kaum transeksual tersebut akhirnya menyesali perubahan yang telah mereka lakukan, stres bahkan mengalami depresi berat yang berkepanjangan yang memicu tindakan bunuh diri. Lalu bagaimana dengan kepuasan seksualnya? Hasil wawancara yang dilakukan oleh Tri Yasni dan Abdillah dengan Prof. Dr. dr. Djohansyah Marzoeki dan dr. Teuku Adifitrian (Yasni dan Abdillah, 2018) menyimpulkan bahwa para transeksual justru tidak mendapatkan kepuasan seksual karena fungsi alat kelamin buatan memang berbeda dengan alat kelamin asli. Alat kelamin buatan pria yang dimiliki bisa gagal ereksi sehingga harus menggunakan alat bantu agar bisa ereksi. Sementara alat kelamin wanita menjadi susah untuk memastikan agar ukuran lubang vaginanya bisa tetap, tidak kebesar dan tidak juga kekecilan. Dengan kata lain, boleh saja diawal pelaku transeksual merasa senang atau menikmati kondisi "barunya" tersebut, tapi sesungguhnya itu hanyalah sementara saja. Kesenangan yang diperoleh hanya bersifat fana dan justru kekecewaan dan penyesalan yang muncul. 
2. Nilai vitalitas atau kesejahteraan atau kehidupan. Mereka yang melakukan perubahan kelamin justru tidak mendapatkan nilai vitalitas kehidupan yang baik. Menurut Hetharia (Hetharia, 2014: 234) nilai vitalitas berhubungan dengan rasa aman karena menyangkut persatuan, keharmonisan dan keseimbangan serta hidup dalam perbedaan dan pembagian. Mereka yang melakukan perubahan kelamin tidak menemukan rasa aman, keharmonisan dan persatuan dengan keluarga dan masyarakat pasca operasi. Justru yang ada adalah rasa minder, kecewa karena tidak diterima oleh keluarga, lingkungan dan agama. Bahkan dikucilkan dari masyarakat menjadi bagian persoalan yang dihadapi yang bisa membawa hal-hal negatif kepada fisik dan mental.

3. Nilai spiritual. Operasi merubah kelamin juga tidak memenuhi aspek nilai spiritual karena nilai spiritual berhubungan dengan kemanusiaan, keadilan dan perdamaian yang merupakan kebutuhan manusia yang hakiki. Menurut Hetharia (Hetharia, 2014: 235), nilai spiritual adalah nilai-nilai yang dicita-citakan dan terus diperjuangkan dalam kehidupan manusia untuk mewujudkan hakikat kemanusiaan yang sejati (kemanusiaan, keadilan dan perdamaian). Justru melalui tindakan merubah alat kelamin ini nilai spiritual hilang karena apa yang diperjuangkan bukanlah nilai-nilai manusia yang hakiki (kemanusiaa, keadilan dan perdamaian) melainkan keinginan pribadi semata untuk sekedar lepas dari "tubuh yang salah." Memang keputusan merubah alat kelamin bagi sebagian orang adalah demi kemanusiaan karena ini menolong orang yang berada dalam kegelisahan akan kondisi dirinya untuk lepas dari kegelisahan itu sekaligus menegakkan hak asasi manusia. Namun, tindakan kemanusiaan dan keadilan itu seharusnya bukanlah secara diputuskan secara subyektif (bersifat kepentingan dan kesenangan pribadi saja) melainkan obyektif (menyangkut dasar-dasar yang pasti) yaitu apakah tindakan itu adalah tindakan kemanusiaan dan keadilan yang bisa atau sudah diterima oleh masyarakat dan agama secara umum.

4. Nilai kekudusan atau keprofanan atau ketuhanan. Dalam diskusi nilai kekudusan ini, yang terkait kepada Sang Pencipta, maka operasi merubah kelamin justru menunjukkan ketidakpuasan akan apa yang Sang Pencipta telah berikan ke dalam hidup manusia. Menurut Hetharia (Hetharia, 2014: 236), nilai kekudusan terkait kepada kesadaran hakiki manusia akan keterbatasannya sebagai makhluk ciptaan dan pengakuan akan Sang Ilahi sebagai pencipta yang mengatur dan mengendalikan seluruh kehidupan manusia dan alam semesta. Nilai ini justru ditentang dalam tindakan merubah alat kelamin pada manusia. Dengan melakukan perubahan pada alat kelamin, seseorang sedang menolak kodrat yang Sang Pencipta telah berikan kepadanya sejak lahir. Mengapa? Pertama, para transeksual menghilangkan dalam dirinya kemampuan untuk bereproduksi karena kelamin yang sudah dirubah. Menurut hasil wawancara yang dilakukan oleh Tri Yasni dan Abdillah dengan Prof. Dr. dr. Djohansyah Marzoeki dan dr. Teuku Adifitrian (Yasni dan Abdillah, 2018), pria yang dirubah alat kelaminnya menjadi perempuan tidak akan pernah bisa hamil. Pada saat yang sama, pria yang sudah merubah alat kelaminnya menjadi perempuan juga tidak akan bisa lagi bereproduksi sebagai seorang pria karena ia sudah tidak mempunyai alat kelamin pria sehingga sperma pun tidak bisa lagi keluar. Demikian juga dengan wanita yang merubah alat kelamin menjadi pria. la tidak akan memiliki sperma yang bisa membuahi sel telur. la juga tidak akan pernah bisa lagi hamil walau masih ada rahim dalam tubuhnya karena ia sudah tidak memiliki alat kelamin perempuan yang melaluinya sperma masuk ke rahim untuk membuahi sel telur dan lubang vagina untuk melahirkan. Kedua, secara kodrat, seandainya para transeksual ini menikah, maka yang terjadi mereka sebenarnya menikah dengan sesama jenis (berdasarkan identitas yang dimiliki waktu lahir) namun dengan kelamin yang berbeda. Bukankah ini menentag kodrat dari Sang Pencipta di mana manusia itu hanya menikah dengan yang berlainan jenis yaitu benar-benar pria dan benar-benar wanita? Ini juga sudah menyangkut Moral Conduct yang terkait pada etika (Edwards, 1967: 106 dan Assalam, 1995: 139). Ketiga, para transeksual merasa bahwa apa yang ia lakukan terhadap dirinya justru membuat dirinya lebih baik dan apa yang Sang Pencipta berikan pada dirinya justru membuat dia menjadi tidak nyaman menjalani kehidupannya. Di sini, pelaku transeksual merasa lebih bijaksana dan lebih tahu apa yang terbaik bagi dirinya sendiri. Padahal bagi orang beriman kepada Tuhan Yang Maha Esa, Tuhan itu Maha Tahu dan Maha Adil. Sang Pencipta akan selalu memberikan yang terbai bagi manusia ciptaanNya. 


\section{Kesimpulan}

Dalam penelitian ini diambil beberapa kesimpulan sesuai dengan rumusan masalah yang dibahas. Aksiologi adalah ilmu yang membahas tentang hakikat nilai. Nilai yang dimaksudkan di sini terkait kepada nilai dan kegunaannya yang tidak terpengaruh oleh subjek maupun pembawanya. Hakikat nilai itu sendiri memiliki hierarki. Ada beberapa hierarki hakikat nilai yang ada. Max Scheler adalah salah satu filsuf yang membagi hakikat nilai ke dalam empat hierarki yaitu: Nilai kenikmatan atau kesenangan dan ketidaknikmatan dan ketidaksenangan; Nilai vitalitas atau kehidupan; Nilai spiritual; dan terakhir Nilai kekudusan atau ketuhanan.

Menyangkut kepada latarbelakang seseorang melakukan operasi perubahan alat kelamin pada dirinya adalah: pertama, pembiaran dari para orang tua di mana orang tua membiarkan anaknya berkembang dalam sikap dan perangai yang tidak sesuai dengan alat genital yang dimiliki. Keadaan ini mendorong rasa tidak puas karena merasa dirinya terjebak di dalam "tubuh yang salah" di mana alat genital yang dimiliki berbeda dengan sifat-sifat yang ia tunjukkan. Terakhir, adanya pertumbuhan alat kelamin yang tidak sempurna. Kelainan seperti ini, menurut medis, dapat diperbaiki melalui operasi kelamin.

Melalui pemaparan yang disampaikan di atas, maka penulis menyimpulkan bahwa operasi merubah kelamin pada manusia tidaklah memiliki hakikat nilai positif atau kegunaan dalam kajian Aksiologi Max Scheler. Ini dikarenakan latarbelakang merubah kelamin bukanlah untuk memberikan kontribusi positif baik kepada nilai-nilai kesenangan, vitalitas, spiritual dan kekudusan. Para pelaku transeksual merasa dirinya terjebak di dalam "tubuh yang salah" sehingga kelompok ini ingin lepas dari perangkap "tubuh yang salah" tersebut. Jalan yang diambil adalah melalui operasi merubah ganti kelamin.

Oleh karena tidak adanya nilai-nilai positif kegunaan di dalam tindakan merubah alat kelamin dalam kajian Aksiologi, maka adalah lebih baik jika pendekatan-pendekatan kejiwaan dan keagamaan diberikan kepada mereka yang merasa terjebak di "tubuh yang salah" tersebut atau yang berperilaku berbeda dari alat genital yang ada. Tujuannya adalah agar etika, norma, nilai-nilai agama yang ada di masyarakat tidak terganggung dan hubungan harmonis yang sudah terjadi selama ini dalam keluarga, masyarakat sosial dan agama dapat terjaga dengan baik. Kedua, mereka yang merasa terjebak dalam "tubuh yang salah" dapat memahami keadaannya yang sebenarnya dan melakukan hal-hal yang pada akhirnya akan memberikan kepastian bagi dirinya bahwa apa yang Sang Pencipta telah berikan kepadanya adalah sesuatu yang terbaik. Sementara yang mengalami kelainan pertumbuhan kelamin, maka penulis menyarankan untuk berkonsultasi dengan pihak medis untuk memahami dengan baik langkahlangkah apa yang sepatutnya diambil agar ketidaksempurnaan pertumbuhan alat genital itu dapat diatasi dengan baik.

\section{Daftar Pustaka}

Anwar, Firdaus. 2018. https://health.detik.com/beritadetikhealth/d3931463/ bagaimana-fungsiseksual-orang-orang-yang-ganti-kelamin. Diakses 18 September 2018.

Assalam, Burhanuddin. 1995. Pengantar Filsafat. Jakarta: Ummi Aksara.

Busro, Abubakar. 1989. Nilai dan Berbagai Aspeknya dalam Hukum: Suatu Pengantar Studi Filsafat Hukum. Jakarta: Bhratara.

Danim, Sudarwan. 2002. Menjadi Peneliti Kualitatif. Bandung: Pustaka Setia.

Edwards, Paul. 1967. The Encyclopedia of Philosophy. New York: Collier Macmillan.

Hetharia, Henky Herzon. 2014. Filsafat Hidup Siwalima dalam Perspektif Aksiologi Max Scheler dan Kontribusinya Bagi Penguatan Karakter Masyarakat Multikultural di Maluku. Disertasi. Fakultas Filsafat Universitas Gadjah Mada, Yogyakarta.

Kaelan, MS. 2002. Filsafat Pancasila. Yogyakarta: Paradigma.

2005. Metode Penelitian Kualitatif Bidang Filsafat. Yogyakarta: Paradigma.

2007. Pendidikan Kewarganegaraan. Yogyakarta: Paradigma. 
Katsoff, Louis O. 2004. Pengantar Filsafat. Diterjemahkan oleh Soejono Soemargono. Yogyakarta: Tiara Wacana.

Klarisa dan Budi Sampurna. 2017. Kepastian Hukum Merubah Jenis Kelamin di Indonesia Ulasan Artikel. Prosiding Pertemuan Ilmiah Tahunan 2017 Perhimpunan Dokter Forensik Indonesia. http://fk.unri.ac. id/wp-content/uploads /2017/08/28.-KLARISA-FIX.pdf. Diakses 18 September 2018.

Kumoro, Panji. 2012. Hakikat Pendidikan Menurut Ki Hadjar Dewantara Tinjauan Aksiologi: Sumbangan Pemikiran Ki Hadjar Dewantara Bagi Pendidikan di Indonesia. Tesis. Fakultas Filsafat Universitas Gadjah Mada, Yogyakarta.

Lacey, Hugh. 1999. Is Science Value Free? Values and Scientific Understanding. London: Routledge.

Maharani, Septiana Dwiputri. 2008. Filsafat Manusia: Unsur-Unsur dan Problematikanya. Yogyakarta: Kepel Press. Press.

Merdekawan, Guntur. 2018. Transgender dan Operasi Kelamin: Sah Secara Medis dan Hukum Indonesia? https://www.kapanlagi.com/showbiz/selebriti/ transgender-38-operasikelamin-sah-secara-medis-38-hukum-indonesia-d297c2-1.html. 20 April 2018. Diakses 18 September 2018.

Mudhofir, Ali. 2014. Mengartikulasi Pendidikan Nilai. Bandung: Alfabeta.

Mulyana, Rohmat. 2004. Mengartikulasikan Pendidikan Nilai. Bandung: Alfabeta.

Peursen, C. A. 1990. Fakta, Nilai, Peristiwa: Tentang Hubungan antara Ilmu Pengetahuan dan Etika. Diterjemahkan oleh A. Sonny Keraf. Jakarta: Gramedia.

Putri, Aisyah. 2016. Rudolf Richter: Kisah Transgender Pertama Dunia yang Jarang Didengar. https://www.boombastis.com/transgender-pertama/85820. Diakses 18 September 2018.

Scheler, Max. 1994. Ressentiment. Translation Lewis B. Coser William W. Holdheim. USA: Marquette University Press.

Subagyo. 2015. Pendidikan Olah Raga Renang dalam Perspektif Aksiologi Relevansinya dengan Fungsi dan Tujuan Pendidikan Nasional. Disertasi. Fakultas Filsafat Universitas Gadjah Mada, Yogyakarta.

Suriasumantri, Jujun S. 2001. Filsafat Ilmu: Sebuah Pengantar Populer. Jakarta: Sinar Harapan.

Wahana, Paulus. 2004. Nilai Etika Aksiologis Max Scheler. Yogyakarta: Kanisius.

Yasni, Tri dan Abdillah. 2018. https://www.kapanlagi.com/showbiz/selebriti/ transgender-38operasi-kelamin-sah-secara-medis-38-hukum-indonesia-d297c2-1.html. Diakses 18 Septeber 2018. 